\title{
Statistical Enhancement of Cyanide Degradation Using Microbial Consortium
}

\author{
Virender Kumar, Vijay Kumar and Tek Chand Bhalla*
}

Department of Biotechnology, Himachal Pradesh University, Summer Hill, Shimla-05, H.P, India

\begin{abstract}
Remediation of cyanide contaminated water bodies using microorganisms is a popular alternative over chemical and physical methods of cyanide detoxification. The objective of the present study is to develop a microbial consortium using three bacteria, i.e., Enterobacter sp. RL2a, Serratia marcescencs RL2b and Achromobacter sp. RL2c for effective degradation of simulated cyanide wastewater. In vitro cyanide degradation was optimum with $2 \%$ inoculum volume of cells; $\mathrm{pH} 6.0,30^{\circ} \mathrm{C}$ temperature at $20 \mathrm{mM}$ substrate concentration leading to complete cyanide removal in $36 \mathrm{~h}$. Response surface methodology (RSM) approach was used for optimization of reaction conditions for cyanide degradation using $5 \mathrm{mg} \mathrm{ml}^{-1}$ resting cells of microbial consortium. Plackett-burman design depicted that three variables viz. time, resting cells of strain $\mathrm{RL} 2 \mathrm{~b}$ and $\mathrm{pH}$ exhibit positive effect on cyanide degradation. The analysis of the quadratic regression model suggested that the model was very significant as correlation coefficient ( 0.847$)$ closer to 1 denotes better correlation between the observed and predicted responses. The model was validated by performing the experiment under optimum conditions, which resulted in $63 \%$ cyanide degradation in $1 \mathrm{~h}$ reaction and complete degradation of $20 \mathrm{mM}$ cyanide in $6 \mathrm{~h}$. By performing factorial design, there was 1.3 fold $(33 \%)$ increases in cyanide degradation.
\end{abstract}

Keywords: Cyanide; Microbial consortium; Response surface methodology

\section{Introduction}

Cyanide containing wastewater is a potent health hazard for humans and components of ecosystems [1].The toxicity of cyanide is quite high due to its ability to poison the respiratory system by inhibiting the final transport of electrons from cytochrome $\mathrm{C}$ oxidase to oxygen, preventing production of ATP. The cyanide containing wastewater is produced by various industries like acrylic fibers and resin production industries, coal industries, cassava starch production industries, plastic production and mining industries etc. [1,2].

The protection of the environment and safety of ecosystems can be maintained by treating wastewater before being discharged into water bodies [3]. Various physical, chemical and biological methods are being used for this purpose. Chemical methods include alkaline chlorination, ozonisation, and wet-air oxidation [4]. High operational cost vis-à-vis generations of chemical wastes are limitations of these processes [5]. However, microbial detoxification of cyanide has emerged as an inexpensive, ecofriendly, and viable alternative to physiochemical processes for the treatment of cyanide in industrial effluents or contaminated sites [6]. The microorganisms reported to degrade cyanide include Bacillus sp. [7], Pseudomonas flourescens [8], Fusarium solani, Trichoderma polysporum, Penicillium miczynski, Azotobacter vinelendi [9] and Serratia marcescens RL2b [10]. Among these, Azotobacter vinelendi degrades $69 \%$ of $4 \mathrm{mmoll}^{-1}$ sodium cyanide while Bacillus sp. $\mathrm{CN}-22$ has been reported to effectively degrade cyanide upto $200 \mathrm{mg} \mathrm{l}^{-1}$ concentration [7] and Serratia marcescens RL2b which is capable of degrading $780 \mathrm{mg} \mathrm{l}^{-1}$ of cyanide in a packed bed reactor completely [5]. However, microorganisms also have their own limitations in terms of growth in specific environment, substrate tolerance and degradation which is evident from previous reports. In the current study, a consortium based approach followed in order to achieve higher substrate tolerance and degradation of cyanide. Three bacterial isolates, Enterobacter sp. RL2a, Serratia marcescens RL2b, and Achromobacter sp. RL2c, which were isolated from different habitats, were identified and then cultivated together in consortium followed by optimization for in vitro cyanide degradation using response surface methodology.

\section{Methodology}

\section{Isolation of cyanide degrading bacteria}

Different samples were collected from rhizosphere soil of cyanogenic plants and industrial wastewater sites of Himachal Pradesh, India. These samples were immediately processed in laboratory for the isolation of cyanide degrading bacteria. Enrichment culture technique using minimal salt medium and glycerol [1\%] and potassium cyanide [780 $\left.\mathrm{mg} \mathrm{l}^{-1}\right]$ as sole source of carbon and nitrogen respectively were used for isolation [10]. After third enrichment, samples were serially diluted and plated on minimal salt medium agar supplemented with potassium cyanide $\left[780 \mathrm{mg} \mathrm{l}^{-1}\right]$. The pure colonies were obtained by streaking on nutrient agar plates. Three best isolates [RL2a, RL2b and RL2c] on the basis of their cyanide degradation potential were selected, identified using biochemical tests [11] and 16S rDNA sequencing data.

\section{Molecular characterization}

Chromosomal DNA of the isolates was extracted manually by Marmur's procedure [12]. The 16S rDNA genes were amplified using polymerase chain reaction with the universal primers $16 \mathrm{~S}$ rDNA for [5'-AGAGTTTGATCCTGGCTCAG-3'] and 16S rDNA Rev [5'-ACGGCTACCTTGTTACGACTT-3'] [Integrated DNA

*Corresponding authors: Tek Chand Bhalla, Department of Biotechnology, Himachal Pradesh University, Summer Hill, Shimla, India, Tel: +91177-2832153; E-mail: bhallatc@rediff.com

Received September 21, 2015; Accepted October 05, 2015; Published October 12, 2015

Citation: Kumar V, Kumar V, Bhalla TC (2015) Statistical Enhancement of Cyanide Degradation Using Microbial Consortium. J Microb Biochem Technol 7: 344-350. doi:10.4172/1948-5948.1000237

Copyright: $\odot 2015$ Kumar V, et al. This is an open-access article distributed under the terms of the Creative Commons Attribution License, which permits unrestricted use, distribution, and reproduction in any medium, provided the original author and source are credited. 
Technologies] and were sequenced at Xcelris Genomics, Ahmedabad, India. Related matching sequences were downloaded from the GenBank database [NCBI, USA] using blast search program [13]. The sequences were aligned using multiple sequence alignment software, Clustal W version 2.0. A phylogenetic tree was constructed with MEGA align software version 5.1 [14] based on the partial 16S rDNA sequences of bacterial species similar to isolate RL2a, RL2b and RL2c.

\section{In vitro cyanide degradation by microbial consortium}

Three selected bacterial isolates were checked for their antagonistic activity. Two bacterial isolates against each other were plated on nutrient agar plates supplemented with cyanide. Different combinations were made and plated. CFU ml- ${ }^{-1}$ [Colony forming units] was also calculated by plating three isolates on nutrient agar plates. Microbial consortium was then optimized in order to achieve maximum cyanide degradation in vitro. Various parameters were taken into account, i.e., inoculum volume, $\mathrm{pH}$, temperature and cyanide concentration. Different combinations viz. consortium (RL2a, RL2b and RL2c); RL2a and RL2b; RL2a and RL2c; RL2b and RL2c; RL2a; RL2b; RL2c were made and biomass $\left(\mathrm{mg} \mathrm{ml}^{-1}\right)$ and percent cyanide degradation was observed after different time intervals.

\section{Optimization of reaction conditions by response surface methodology [RSM]}

Plackett Burman design was used to screen the factor having positive effect on degradation of cyanide by microbial consortia. Various reaction parameters and physical parameters were screened for nine variables at two levels, minimum and maximum. Nine different variables, i.e., $\mathrm{pH}(5.0-9.0)$, temperature $\left(20-40{ }^{\circ} \mathrm{C}\right)$, strain RL2a $(50-200 \mu \mathrm{l})\left(1.5 \mathrm{mg} \mathrm{ml}^{-1}\right)$, strain RL2b $(50-200 \mu \mathrm{l})\left(1.5 \mathrm{mg} \mathrm{ml}^{-}\right.$ $\left.{ }^{1}\right)$, and strain RL2c $(50-200 \mu \mathrm{l})\left(1.0 \mathrm{mg} \mathrm{ml}^{-1}\right)$, time of reaction $(10-100$ $\mathrm{min})$, concentration of substrate $(1-20 \mathrm{mM})$, volume of reaction (1-2 $\mathrm{ml})$ and $\mathrm{rpm}(0-150)$ by performing 12 experiments. Design Expert (Version 8.0.4) was used for Plackett-Burman design and regression analysis. Pareto chart was constructed to find out the positive variable which effect cyanide degradation.

\section{Optimization of selected variable using central composite design (CCD)}

The concentration of different independent variables which showed positive effect ( $\mathrm{pH}$, time strain $\mathrm{RL} 2 \mathrm{~b}$ ) for cyanide degradation was optimized by using Central Composite Design (CCD). Second-order polynomial coefficient were calculated and analyzed by using Design Expert software 8.0.4.

\section{Validation of statistical model}

The statistical model was validated for the degradation of cyanide by performing experiment at shake flask under predicted set of conditions.

\section{Assay method}

Samples withdrawn in small aliquots at different intervals of time were centrifuged and the degradation of cyanide in the supernatant was assayed using picric acid assay method [15]. Absorbance was measured at $520 \mathrm{~nm}$ and concentration of cyanide was calculated from standard curve of cyanide estimation (prepared by assaying KCN ranging from $\left.1.5 \mu \mathrm{mol} \mathrm{l}^{-1}-13.5 \mu \mathrm{mol} \mathrm{l}^{-1}\right)$.

\section{Statistical analysis}

All the reactions were carried out in triplicates and error bars represent the standard deviation.

\section{Results}

\section{Isolation of cyanide degrading bacteria}

Three cyanide degrading bacteria were selected after screening of eighty six isolates. Morphological examination of colonies of RL2a and RL2b and RL2c (Figure 1) isolates on agar plate showed them to be creamish white in color, concave, smooth and wet. The cells were large and rod like in case of RL2a (Gram negative) and RL2b (Gram negative) whereas, RL2c (Gram negative) had coccal rod like cells. The biochemical characteristics of the isolates are given in Table 1. No antagonistic activity was observed among these isolates.

\section{Molecular characterization}

The partial $16 \mathrm{~S}$ rDNA sequences of RL2a, RL2b and RL2c were determined and phylogenetic tree was constructed (Figure 2). Comparison of ribosomal DNA gene sequence analysis revealed a strong relationship between isolate RL2a and members of genus Enterobacter, RL2b and members of genus Serratia and RL2c and members of genus Achromobacter. The isolate RL2a had 99\% sequence similarity with Enterobacter sp.; RL2b had $98 \%$ sequence similarity with Serratia marcescens strain XJU PA-6 and RL2c had 99\% sequence similarity with that of Achromobacter sp. The sequences were deposited in GenBank database with accession number KF225466, JX549409 and KF225467, respectively. On the basis of physiological and biochemical characteristics and results of $16 \mathrm{~S}$ rDNA gene sequence comparison, the selected isolates were identified as Enterobacter sp. RL2a, Serratia marcescens RL2b and Achromobacter sp. RL2c (Figure 2).

\section{In vitro cyanide degradation by microbial consortia}

The antagonistic effect of selected bacterial isolates was studied in order to check whether the consortium components coexist with each other or not. The results showed that bacterial isolates do not interfere with each other during growth in culture medium. A very little difference in degradation rate was observed by the bacteria when different percentage of initial inoculum volume was used (Figure 3). Thus, the initial $2 \%$ inoculum volume of cultures was used for further experiments. Near neutral $\mathrm{pH}$ values support degradation of cyanide as well as the growth of consortia as evident from Figure 4. Cyanide degradation was maximum at $\mathrm{pH} 6.0$ and it went on decreasing with increase in $\mathrm{pH}$. Time course of cyanide degradation was also reduced from $60 \mathrm{~h}$ to $48 \mathrm{~h}$. In the present investigation, 99\% degradation of cyanide was observed at $30^{\circ} \mathrm{C}$ with biomass of $5 \mathrm{mg} \mathrm{ml}^{-1}$ (Figure 5). Maximum cyanide concentration which could be tolertated by consortium is $20 \mathrm{mM}$ (Figure 6).

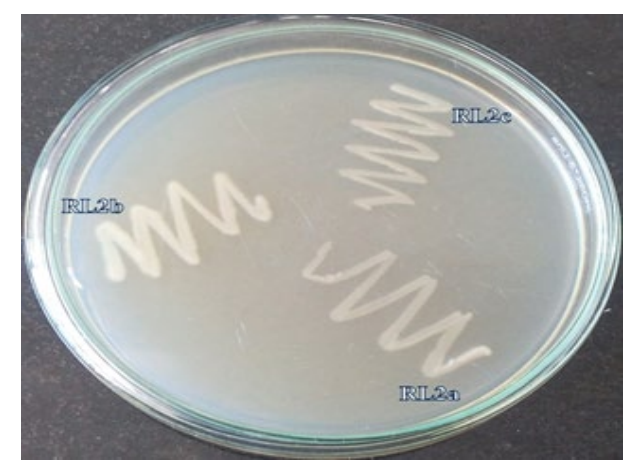

Figure 1: Bacterial isolates Enterobacter sp. RL2a, Serratia marcescens RL2b and Achromobacter sp.RL2c on nutrient agar plate. 
Citation: Kumar V, Kumar V, Bhalla TC (2015) Statistical Enhancement of Cyanide Degradation Using Microbial Consortium. J Microb Biochem Technol 7: 344-350. doi:10.4172/1948-5948.1000237

\begin{tabular}{|c|c|c|c|c|c|c|c|}
\hline \multirow{2}{*}{ Characteristics } & \multicolumn{3}{|c|}{ Properties } & \multirow{2}{*}{ Characteristics } & \multicolumn{3}{|c|}{ Properties } \\
\hline & RL2a & RL2b & RL2c & & RL2a & RL2b & RL2c \\
\hline Gram staining & - & - & - & Sucrose & + & + & - \\
\hline Oxidase & _ & - & + & Adonitol & + & + & _- \\
\hline Catalase & + & + & + & Glucose & + & + & + \\
\hline Citrate utilization & + & + & _ & Cyanide & + & + & + \\
\hline $\mathrm{H}_{2} \mathrm{~S}$ production & - & - & - & D-Fucose & + & + & - \\
\hline Nitrate reduction & + & + & - & D-Sorbitol & + & + & - \\
\hline D-mannitol & + & + & - & L-Arabinose & + & + & - \\
\hline D-Maltose & + & + & 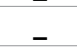 & Indole Production & - & - & 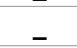 \\
\hline Lysine Decarbooxylase & _ & - & + & DNase & + & + & + \\
\hline Ornithine decarboxylase & + & + & + & Trehlose & + & + & - \\
\hline
\end{tabular}

Table 1: Biochemical characteristics of isolates RL2a, RL2b and RL2c.

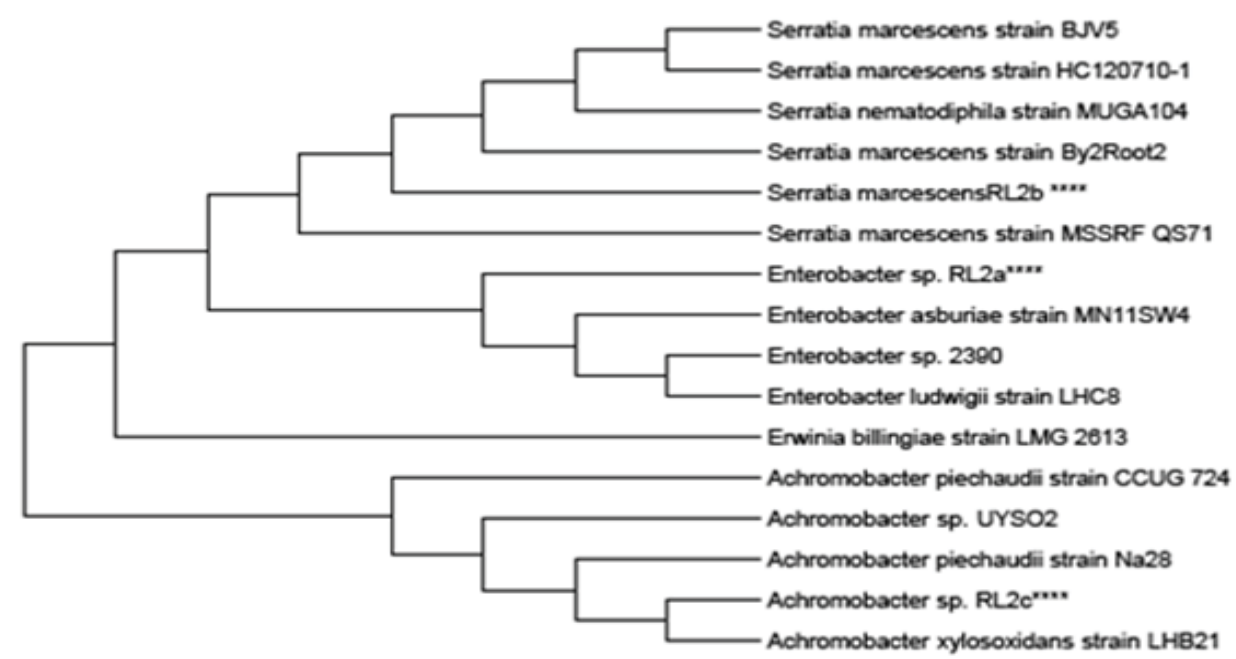

Figure 2: Phylogenetic tree of components of microbial consortium.

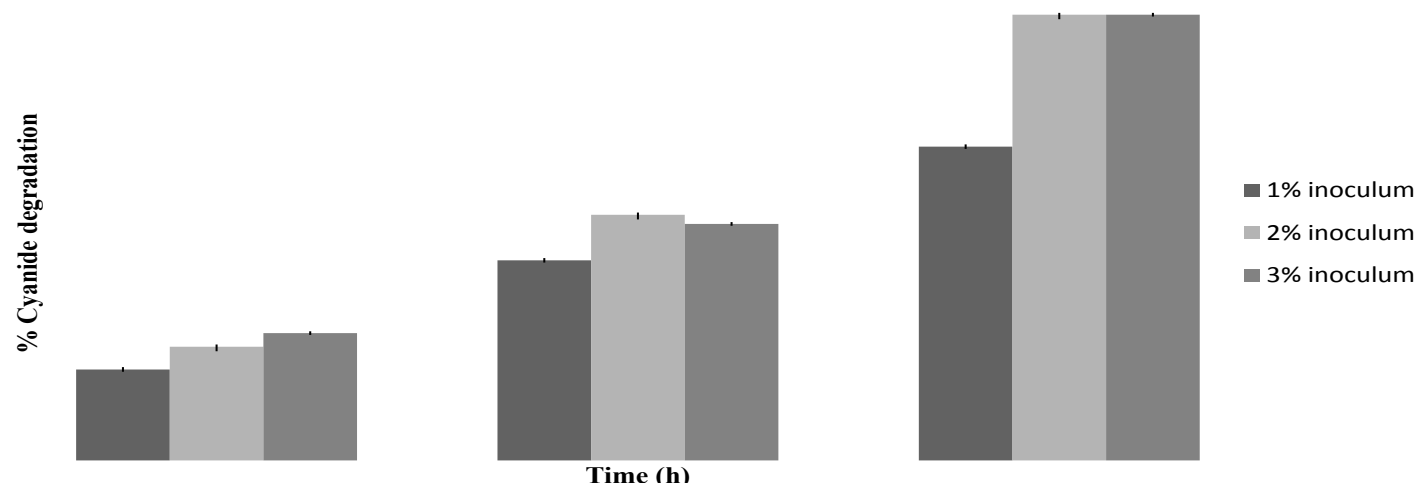

Figure 3: Percent cyanide degradation of cyanide at different inoculum volume.

\section{Comparative study of bacterial cyanide degradation using} different combinations

Complete degradation of cyanide was observed in consortium with high biomass concentration $\left(5 \mathrm{mg} \mathrm{ml}^{-1}\right)$ after $36 \mathrm{~h}$. Bacterial isolate RL2c also showed good degradation. Combination of RL2a and RL2c also showed $80 \%$ degradation. But maximum degradation was recorded in consortium which revealed the synergetic effect of all components of consortia (Figure 7).
Factorial design for enhancing cyanide degradation by resting cells of microbial consortium

Screening of important parameters using plackett-burman design : Resting cells of components of microbial consortium were prepared and harvested after $36 \mathrm{~h}$ at $6000 \mathrm{x}$ g for $10 \mathrm{~min}$. These cells were then utilized to screen important parameters using PlackettBurman design. Various parameters used in the study are listed in Table 2. Total of nine variables were used in the study. Pareto chart 


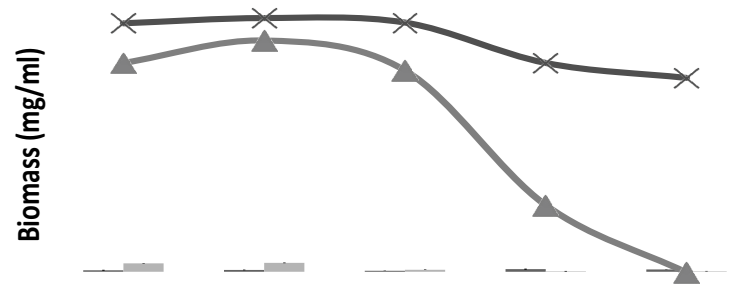

pH
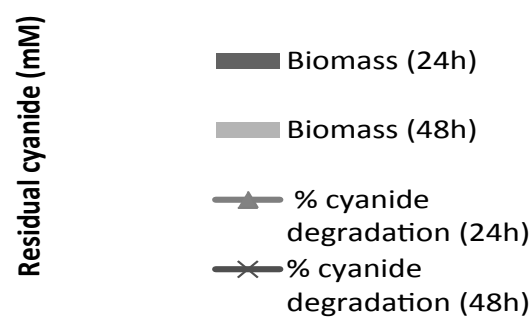

Figure 4: Biomass $\left(\mathrm{mg} \mathrm{ml}^{-1}\right)$ and percent degradation of cyanide of consortium at different $\mathrm{pH}$.

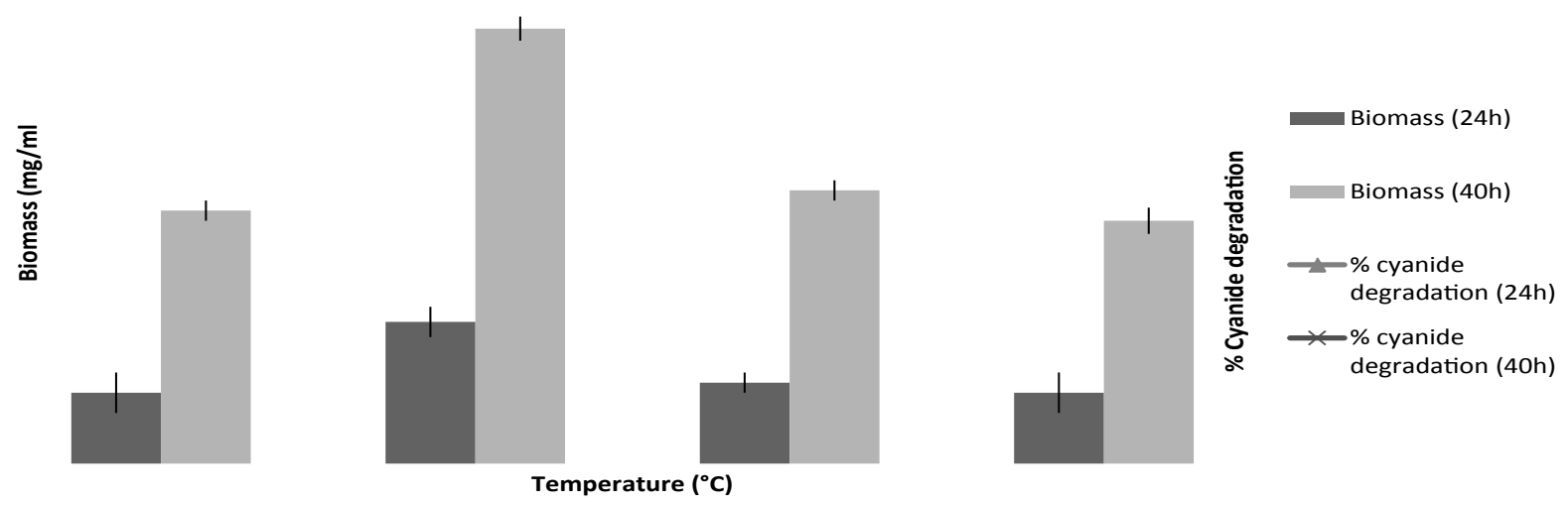

Figure 5: Biomass $\left(\mathrm{mg} \mathrm{ml}^{-1}\right)$ and percent degradation of cyanide of consortium at different temperatures.
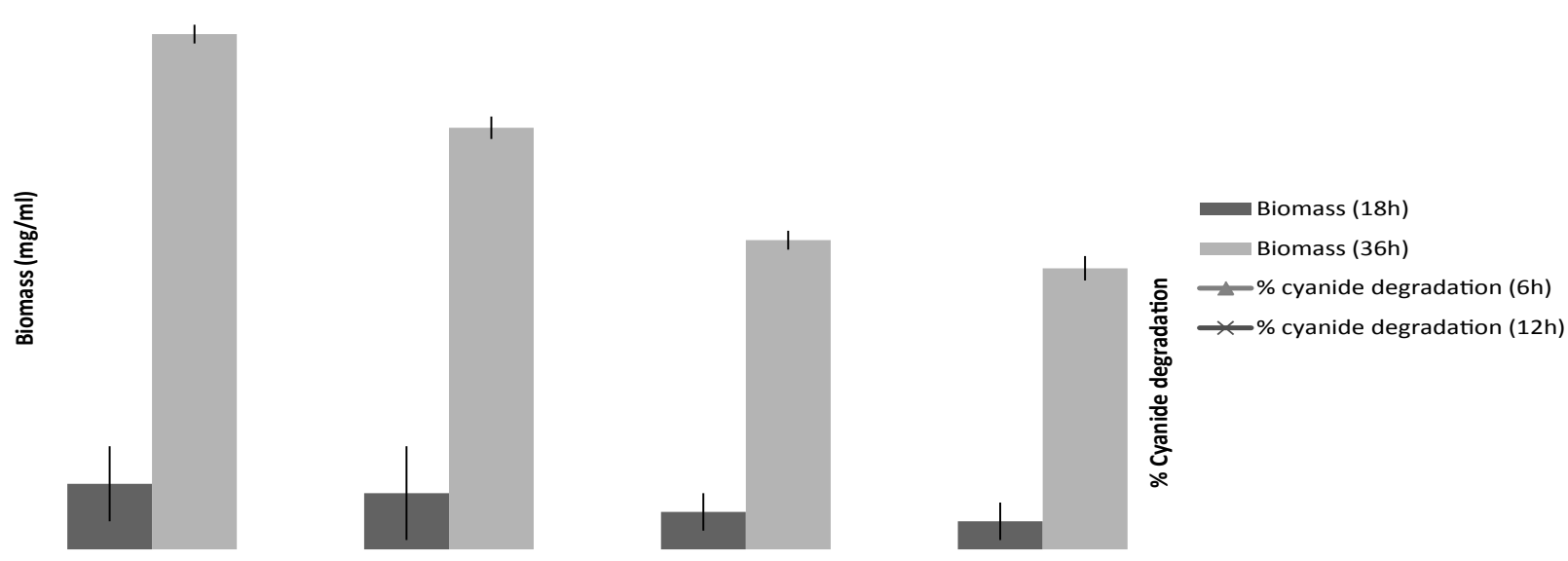

Cyanide concentration ( $\mathrm{mM}$ )

Figure 6: Biomass $\left(\mathrm{mg} \mathrm{ml}^{-1}\right)$ and percent degradation of cyanide of consortium at different cyanide concentrations.

was constructed to find out the positive variables which affect cyanide degradation (Figure 8). Three variables i.e. time, resting cells of isolate $\mathrm{RL} 2 \mathrm{~b}$ and $\mathrm{pH}$ had shown positive effect on cyanide degradation while other factors had shown a negative effect. Subsequent experiments were performed using these three variables in central composite design.

Central composite design: For the determination of optimum level and combined effect of different variables $(\mathrm{pH}$, time and strain RL2b), a central composite design was used, and a second order polynomial equation was derived to explain the dependence of cyanide degradation on these three variables by microbial consortium.
Lack of fit test for CCD model: ANOVA analysis of the central composite design (CCD) results was performed and four process orders were suggested by Design Expert 8.0.4. Quadratic process order proved best and used for further analysis due to low standard deviation (0.109), high R-squared value (0.847) and low press value (0.15) for further analysis. The analysis of the quadratic regression model suggested that the model was very significant as correlation coefficient (0.847) closer to 1 denotes better correlation between the observed and predicted responses (Table 3 ). Three-dimensional plots were generated for regression analysis of CCD design of pair wise combination of 


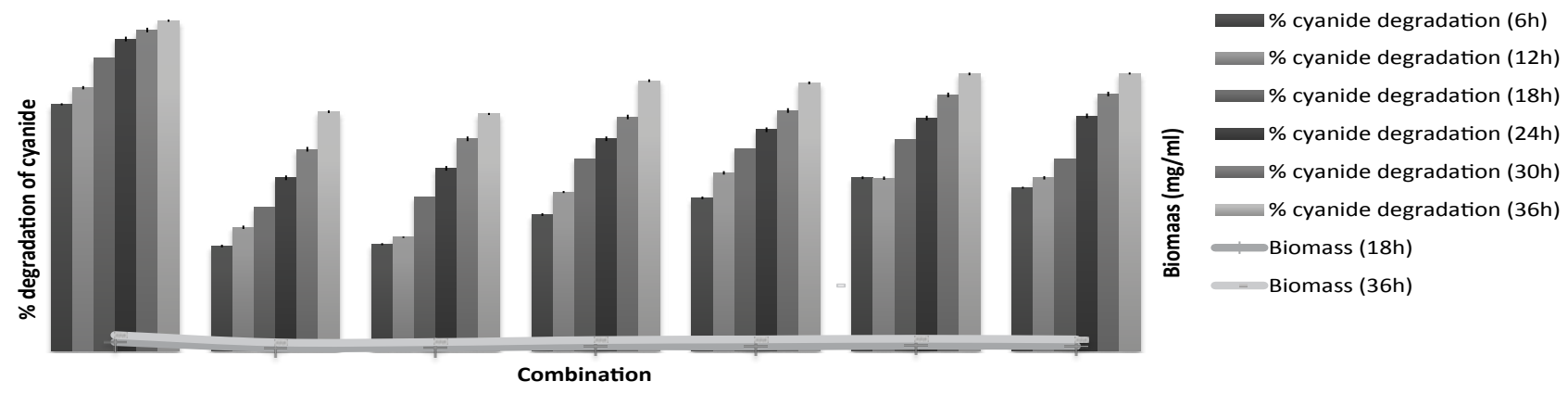

Figure 7: Biomass $\left(\mathrm{mg} \mathrm{ml}^{-1}\right)$ and percent degradation using various combinations.

\begin{tabular}{|c|c|c|c|c|c|c|c|c|c|c|c|}
\hline Std & Run & $\mathrm{pH}$ & Temperature & RL2a $(\mu \mathrm{l})$ & RL2b $(\mu \mathrm{l})$ & RL2c ( $\mu \mathrm{l})$ & Time (Min) & Substrate $(\mathrm{mM})$ & volume $(\mathrm{ml})$ & rpm & Response (\% degradation) \\
\hline 11 & 1 & 9 & 20 & 200 & 200 & 200 & 10 & 1 & 1 & 100 & 7 \\
\hline 8 & 2 & 9 & 40 & 50 & 50 & 50 & 100 & 1 & 2 & 100 & 64 \\
\hline 12 & 3 & 5 & 20 & 50 & 50 & 50 & 10 & 1 & 1 & 0 & 86 \\
\hline 1 & 4 & 9 & 40 & 50 & 200 & 200 & 100 & 1 & 1 & 0 & 81 \\
\hline 5 & 5 & 5 & 20 & 200 & 50 & 200 & 100 & 1 & 2 & 100 & 89 \\
\hline 3 & 6 & 9 & 20 & 200 & 200 & 50 & 100 & 20 & 2 & 0 & 55 \\
\hline 10 & 7 & 5 & 40 & 200 & 200 & 50 & 10 & 1 & 2 & 0 & 37 \\
\hline 9 & 8 & 9 & 40 & 200 & 50 & 50 & 10 & 20 & 1 & 100 & 15 \\
\hline 7 & 9 & 9 & 20 & 50 & 50 & 200 & 10 & 20 & 2 & 0 & 19 \\
\hline 2 & 10 & 5 & 40 & 200 & 50 & 200 & 100 & 20 & 1 & 0 & 51 \\
\hline 6 & 11 & 5 & 20 & 50 & 200 & 50 & 100 & 20 & 1 & 100 & 48 \\
\hline 4 & 12 & 5 & 40 & 50 & 200 & 200 & 10 & 20 & 2 & 100 & 43 \\
\hline
\end{tabular}

Table 2: Screening of important parameters using Plackett-Burman design.

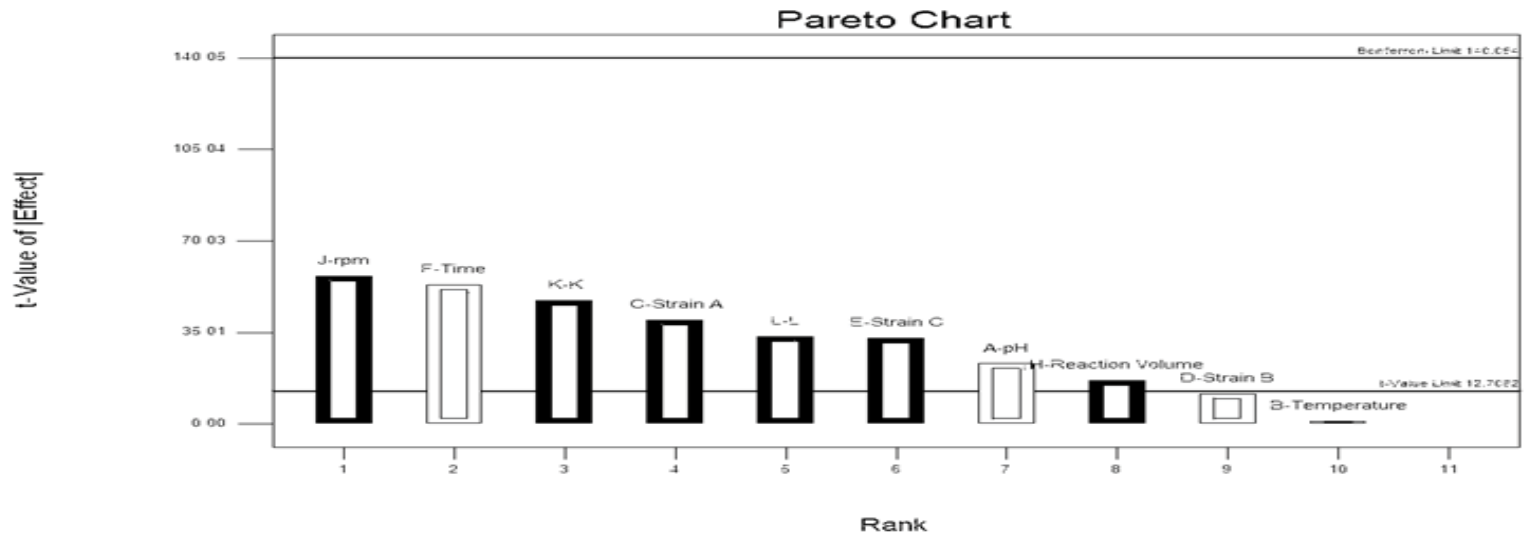

Figure 8: Plackett-Burman design showing the effect of different factors on cyanide degradation (light black color (positive factors) and dark black (negative)

three factors for cyanide degradation. The effects of the independent variables and combined effects of each independent variable upon the response variable were described by plotting $3 \mathrm{~d}$ graphs (Figure 9a-9d).

Validation of model: The maximum cyanide degradation was achieved by performing experiment on the basis of the above statistical information. Perturbation plot (Figure 9a) showed the optimum value for variable $\mathrm{pH} 7.0$, time $55 \mathrm{~min}$ and $125 \mu \mathrm{l}$ cells of strain RL2c $(1.5 \mathrm{mg}$ $\left.\mathrm{ml}^{-1}\right)$. The model was validated by performing the experiment under optimum conditions, which resulted in $63 \%$ cyanide degradation. By performing factorial design, there was 1.3 fold (33\%) increases in cyanide degradation.

\section{Discussion}

Eighty six cyanide degrading microbes were isolated from various soil and water samples. Soil samples were collected either from rhizosphere of cyanogenic plants e.g. cassava, peach, almond and apple because these places have more possibility and probability due to continuous enrichment of soil with different cyanogenic compounds released for defense purposes. Water samples were collected from electroplating, pesticide and textile industries which were using simple and complex cyanides. Three best cyanide degrading isolates were selected after screening. These isolates were then monitored for 


\begin{tabular}{|c|c|c|c|}
\hline Model & Standard Deviation & $\mathbf{R}^{\mathbf{2}}$ (Actual) & \multicolumn{2}{|c|}{$\mathbf{R}^{\mathbf{2}}$ (Predicted) } \\
\hline Linear & 0.143 & 0.577 & 0.356 \\
\hline 2FI & 0.151 & 0.616 & -0.734 \\
\hline Quadratic & $\mathbf{0 . 1 0 9}$ & $\mathbf{0 . 8 4 7}$ & $\mathbf{0 . 8 7 6}$ \\
\hline Cubic & 0.010 & 0.999 & Suggested \\
\hline
\end{tabular}

Table 3: Standard deviation and $\mathrm{R}^{2}$ values for the model.

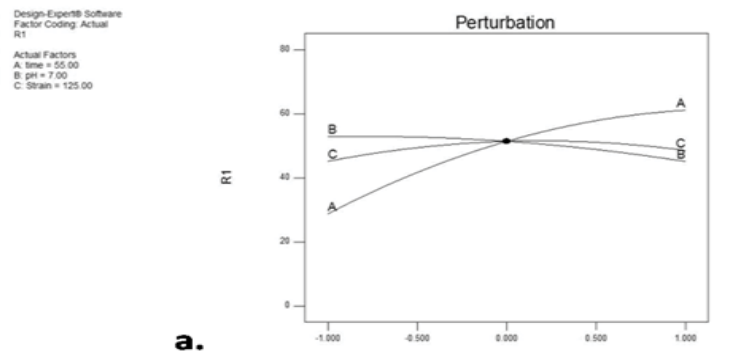

a.

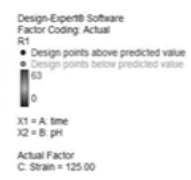

$\bar{\alpha}$

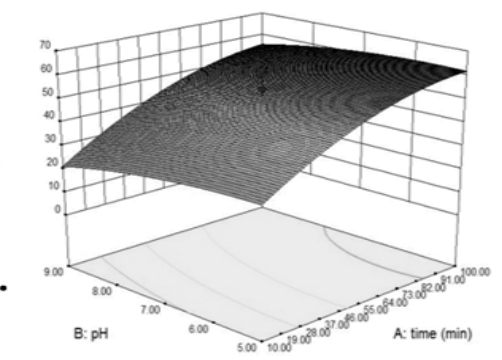

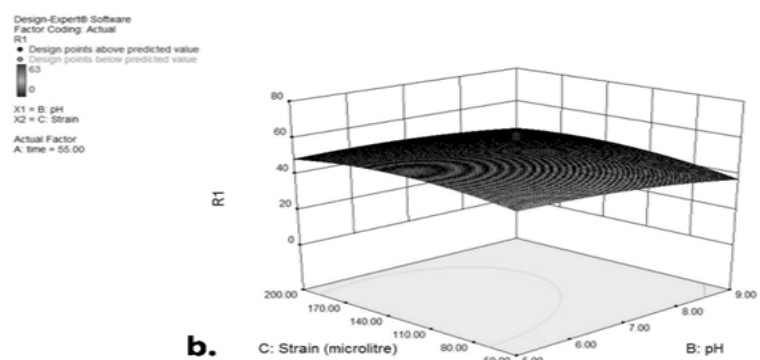

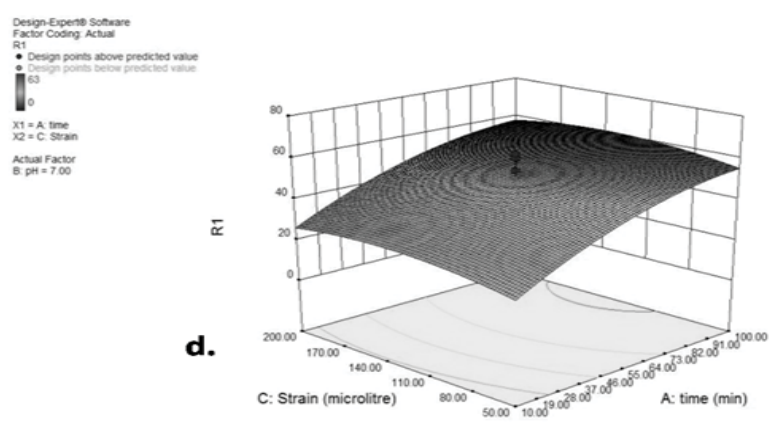

Figure 9: (a-d) (a) Perturbation plot showing deviation of variables from reference point. (b) Three dimensional graph showing effect of two variable interactions $\mathrm{B}$ : $\mathrm{pH}$ and C: strain RL2b (c) B: pH and A: time (d) A: time and C: strain RL2b on cyanide degradation.

their antagonistic activity against each other which is very important property for consortium development. No antagonistic activity was found in these isolates. Three isolates were then identified by various biochemical and morphological features and 16S rDNA sequencing. These were gram negative, catalase positive and produce $\mathrm{H}_{2} \mathrm{~S}$ (Table 1). The phylogenetic studies of the organisms using Clustal Omega and Mega Align software were carried out (Figure 1). Enterobacter sp. RL2a and Achromobacter sp. RL2c are being reported for the first time as cyanide degrading microorganisms. Serratia marcescens RL2b has been previously reported as an efficient cyanide degrading bacterium [10].

The volume of the initial culture, incubation temperature, $\mathrm{pH}$ and substrate concentration supplemented with appropriate ratio of carbon, nitrogen and other nutrients added to the medium control microbial growth and activity [16]. The authors reported that degradation efficiency was poor in media that were supplemented with Beta valgaris, Ipomoea batatas, Ananas comosus and spent brewer's yeast extracts at all the cyanide concentrations evaluated $(400 \mathrm{mg}$ $\mathrm{l}^{-1}$ ). The ability of the white rot fungus Trametes versicolor to degrade cyanide at a maximum cyanide concentration of $400 \mathrm{mg} \mathrm{CN} \mathrm{l}^{-1}$, where the degradation efficiency was less than $30 \%$ was reported [17]. The immobilized cells of Klebsiella oxytoca were used for the degradation cyanide at a maximum concentration of $157 \mathrm{mg} \mathrm{CN}^{-1} \mathrm{l}^{-1}$ where the microbe had achieved a degradation efficiency of $26 \%$ when cellulose acetate was used as a carbon source [18]. The bioaugmentation of cyanide coke waste water $\left(14 \mathrm{mg} \mathrm{l}^{-1}\right)$ using Cryptococcus humicolus and an unidentified cyanide degrading organism was reported [19]. At high concentration ( $500 \mathrm{mg} \mathrm{l}^{-1}$ ), only about $45 \%$ of cyanide was degraded within 4 days using bacterial isolate C2 [20]. Bacillus sp. CN22 was isolated from a cyanide-contaminated electroplating sludge and found to be able to tolerate a $\mathrm{CN}^{-}$concentration of $700 \mathrm{mg} \mathrm{l}^{-1}$ [7]. Klebsiella oxytoca can remain active at a $\mathrm{CN}^{-}$concentration of $26 \mathrm{mg} \mathrm{l}^{-1}$ [21] and the immobilized cells of $K$. oxytoca could tolerate a higher $\mathrm{CN}^{-}$concentration of $78 \mathrm{mg} \mathrm{l}^{-1}$ [18]. Azotobacter vinelandii has $\mathrm{CN}^{-}$resistance at $104 \mathrm{mg} \mathrm{l}^{-1}$ [22], and Serratia marcescens RL2b could tolerate $780 \mathrm{mg} \mathrm{l}^{-1}$ of potassium cyanide [10] which is the highest concentration of cyanide tolerated by microorganisms reported so far. In present study, minimal salt medium [23] was used, supplemented with glycerol and yeast extract for growth and $15 \mathrm{mM}$ cyanide $(930 \mathrm{mg}$ $\mathrm{l}^{-1}$ ) in order to reduce the overall cost of operation.

Maximum cyanide degradation ( $99 \%$ ) was achieved with $2 \%$ initial volume of culture (consortium) in vitro, $30^{\circ} \mathrm{C}$ temperature and $\mathrm{pH}$ 6.0. The initial time ( 3 days) used for complete degradation of added cyanide was reduced to one and a half day ( $36 \mathrm{~h}$ ) by optimizing culture conditions. Consortium degrades cyanide efficiently in acidic $\mathrm{pH}(6.0)$. With the increase in $\mathrm{pH}$ degradation rate falls. The decrease may be due to non-availability of favorable environment for the isolates at high pH. Microbial consortium is mesophilic in nature. Maximum concentration of cyanide that can be tolerated by the consortium reflects the degradation potential of the components of consortium. The bacterial isolates were used in different combinations to see whether the combination of microorganisms used for consortia worked well or some other combinations for efficient cyanide removal are required. Comparative analysis revealed that the combination used in the study worked very well for cyanide degradation. It can be depicted that an 
increase in concentration of cyanide from $20 \mathrm{mM}$ leads to retardation of growth (Figure 4) which may be due to denaturing of bacterial repiratory enzymes at high cyanide that ultimately leads to less ATP production hence decrease in growth. $20 \mathrm{mM}$ of cyanide was degraded completely in $36 \mathrm{~h}$.

The Response Surface Methodology (RSM) was used in evaluation of optimization of biodegradation of cyanide in reactions. This method is based on analysis of response as affected by some factors and its objective is to determine the optimum condition of the response. The important factors which affect cyanide biodegradation were $\mathrm{pH}$, time and strain RL2c. The analysis of variance (ANOVA) of the quadratic model demonstrates that the model was highly significant for bacterial isolates C2 [20]. Zhu et al. used RSM to determine the optimum levels of different variables in the microwave-assisted extraction of astaxanthin from Phaffia rhodozym. The cyanide content decreased with increasing temperature and $\mathrm{pH}$ in the range of 30 to $36^{\circ} \mathrm{C}$ and $9-10.5$, respectively. However, the degradation rate was reduced for a further increase in temperature and $\mathrm{pH}$ value. The optimum conditions were at $23^{\circ} \mathrm{C}$, $\mathrm{pH} 10.3$ and glucose concentration $0.44\left(\mathrm{~g} \mathrm{l}^{-1}\right)$ which could provide $24 \mathrm{ppm}$ for predicted cyanide content and $26 \mathrm{ppm}$ for experimental content [20]. Bacillus sp. CN-22, which could tolerate the highest $\mathrm{CN}^{-}$ concentration of $700 \mathrm{mg} \mathrm{l}^{-1}(11 \mathrm{mM})$, under the optimal conditions of $193 \mathrm{rpm}$ rotary speed, $2.38 \%$ inoculum, $31^{\circ} \mathrm{C}$ temperature, 10.3 initial $\mathrm{pH}$, and the $\mathrm{CN}^{-}$concentration in the effluent was reduced from 200 to $6.62 \mathrm{mg} \mathrm{l}^{-1}$ after incubation for $72 \mathrm{~h}$. A mesophilic alkali-tolerant bacterial consortium belonging to the Bacillus genus was evaluated for its ability to biodegrade high free cyanide $(\mathrm{CN}-)$ concentration (up to $500 \mathrm{mg} \mathrm{CN} \mathrm{l}^{-1}$ ), subsequent to the oxidation of the formed ammonium and nitrates in a continuous bioreactor system solely supplemented with whey waste. The whey supported Bacillus sp. culture was not inhibited by the free cyanide concentration of up to $500 \mathrm{mg} \mathrm{CN}^{-1}$, with an overall degradation efficiency of $\geq 99 \%$ with subsequent nitrification and aerobic denitrification of the formed ammonium and nitrates over a period of 80 days [24,25]. However, the problems with above mentioned alternatives are low cyanide tolerance, high $\mathrm{pH}$ and low degradation rate using single microorganism. To avoid these drawbacks, microbial consortium was developed which exhibit high cyanide tolerance at near neutral $\mathrm{pH}$ [6-6.5] and optimum temperature $\left(30^{\circ} \mathrm{C}\right)$. Response surface methodology studies showed that the quadratic model works well for the consortium attaining $63 \%$ degradation in single hour for $20 \mathrm{mM}\left(1300 \mathrm{mg} \mathrm{l}^{-1}\right)$ cyanide. A total of 1.3 fold increase in degradation rate was achieved. Complete degradation of $20 \mathrm{mM}$ cyanide was achieved in $6 \mathrm{~h}$.

\section{Conclusion}

The consortium developed in the present study could degrade 20 $\mathrm{mM}$ cyanide completely in simulated wastewater and tolerate $30 \mathrm{mM}$ at $30^{\circ} \mathrm{C}$ and $\mathrm{pH} 6.0$. Response surface methodology approach resulted in 1.3 fold increase in cyanide degradation. Removal of cyanide from waste water using combination of microorganisms proved to be a better approach. The consortium have shown highest rate of degradation and tolerance for cyanide among the hitherto reported microbial systems.

\section{References}

1. Hamel J (2011) A review of acute cyanide poisoning with a treatment update. Crit Care Nurse 31: 72-81.

2. Potivichayanon S, Kitleartpornpairoat $R$ (2010) Biodegradation of cyanide by a novel cyanide degrading bacterium. W Acad Sci Eng Technol 66: 1376-1379.

3. Luque-Almagro VM, Blasco R, Martinez-Luque M, Moreno-Vivian C, Castillo $\mathrm{F}$, et al. (2011) Bacterial cyanide degradation is under review: Pseudomonas psedoalcaligenes CECT5344, a case of an alkaliphilic cyanotroph. Biochem Soc Trans 39: 269-74.

4. Kao CM, Lin CC, Liu JK, Chen YL, Wu LT, et al. (2004) Biodegradation of metalcyano complex tetracyanonickelate (II) by Klebsiella oxytoca. Enz Microbial Technol 35: 405-410.

5. Kumar V, Kumar V, Bhalla TC (2015) Packed bed reactor for degradation of simulated cyanide containing waste water. 3 Biotech 5: 641-646.

6. Huertas MJ, Sáez LP, Roldán MD, Luque-Almagro VM, Martínez-Luque M, et al. (2010) Alkaline cyanide degradation by Pseudomonas pseudoalcaligenes CECT5344 in a batch reactor. Influence of pH. J Hazard Mater 179: 72-78.

7. Wu CF, Feng AJ, Xu XM, Huang SH, Deng MC, et al. (2013) Construction of recombinant Pichia strain GS115-Ch-Glu expressing ß-glucosidase and cyanide hydratase for cyanogenic glycosides detoxification. Afri J Biotechnol 11: 4424-4423.

8. Dursun AY, Calik A, Aksu Z (2009) Degradation of ferrous (II) cyanide complex ion by Pseudomonas flourescens. Process Biochem 34: 901-908.

9. Dash RR, Gaur A, Balomajumder C (2009) Cyanide in industrial wastewaters and its removal: A review on biotreatment. J Hazard Mater 163: 1-11.

10. Kumar V, Kumar V, Bhalla TC (2013) In vitro cyanide degradation by Serratia marcescens RL2b. Int J Environ Sci 3: 1985-1995.

11. Sambrook J, Russel DW (2006) The condensed protocols from molecular cloning: A laboratory manual. Cold spring harbor laboratory press, New York.

12. Holt JS, Krieg NR, Sneath PHA, Staley JT, Williams ST (1994) Bergey's manual of determinative bacteriology. ( $9^{\text {th }}$ Edn) Williams and Wilkins, 216-218.

13. Altschul SF, Gish W, Miller W, Myers EW, Lipman DJ (1990) Basic local alignment search tool. J Mol Biol 215: 403-410.

14. Tamura K, Peterson D, Peterson N, Stecher G, Nei M, et al. (2011) MEGA5 Molecular Evolutionary Genetics Analysis using maximum likelihood, evolutionary distance and maximum parsimony methods. Mol Biol Evol 28 2731-2739.

15. Fisher FB, Brown JS (1952) Colorimetric determination of cyanide in stack gas and waste water. Anal Chem 24: 1440-1444.

16. Ghazali, Zaliha RN, Rahman A, Salleh AB, Basri M (2004) Biodegradation of hydrocarbons in soil by microbial consortium. Int Biodeter Biodegr 54: 61-67.

17. Cabuk A, Unal AT, Kolankaya N (2006) Biodegradation of cyanide by a white rot fungus, Trametes versicolor. Biotechnol Lett 28: 1313-1317.

18. Chen CY, Kao CM, Chen SC, Chen TY (2009) Biodegradation of by Klebsiella oxytoca under anaerobic conditions. Desalination 249: 1212-1216.

19. Park D, Lee DS, Kim YM, Park JM (2008) Bioaugmentation of cyanidedegrading microorganisms in a full-scale cokes wastewater treatment facility. Bioresour Technol 99: 2092-2096.

20. Mirizadeh S, Yaghmaei S, Ghobadi Nejad Z (2014) Biodegradation of cyanide by a new isolated strain under alkaline conditions and optimization by response surface methodology (RSM). J Environ Health Sci Eng 12: 85.

21. Chena SC, Liu JK (1999) The respiratory responses to cyanide of a cyanideresistant Klebsiella oxytoca bacterial strain. FEMS Microbiol Lett 175: 37-43.

22. Koksunan S, Vichitphan S, Laopaiboon L, Vichitphan K, Han J (2013) Growth and cyanide degradation of Azotobacter vinelandii in cyanide-containing wastewater system. J Microbiol Biotechnol 23: 572-578.

23. Bhalla TC, Miura A, Wakamoto A, Ohba Y, Furuhashi K (1992) Asymmetric hydrolysis of a-aminonitriles to optically active amino acids by a nitrilase of Rhodococcus rhodochrous PA-34. App Microbiol Biotechnol 37: 184-190.

24. Mekuto L, Karabo S, Ntwampe O, Jackson VA (2015) Biodegradation of free cyanide and subsequent utilization of biodegradation by-products by Bacillus consortia: Optimization using response surface methodology. Environ Sci Pollut Res 22: 10434-10443.

25. Zhu C, Han W, Chen Z, Han Z (2010) Statistical optimization of microwaveassisted astaxanthin extraction from Phaffia rhodozym. Biomedical Engineering and Informatics 5: 2104-2109. 